\title{
Vloga nosilcev izvršilne oblasti in parlamentov držav članic v Evropski uniji (EU)
}

UDK 321.72:342. (1.924)

\author{
Rudi Kocjančič \\ Fakulteta za upravo \\ rudi.kocjancic@fu.uni-lj.si
}

\section{IZVLEČEK}

Pisec obravnava vlogo nosilcev izvršilne oblasti in parlamentov držav članic $\mathbf{v}$ Evropski uniji (EU). Pri tem ugotavlja, da imajo nosilci izvršilne oblasti teh držav sistemski primat $v$ institucijah te organizacije in da je vloga Evropskega parlamenta $v$ EU drugorazredna. Posebej analizira in problematizira omejeni vpliv nacionalnih parlamentov na opravljanje zakonodajne funkcije te organizacije.

Po piščevem mnenju tudi osnutek ustavne pogodbe ne odpira institucionalnih možnosti za neposredno sodelovanje nacionalnih parlamentov pri opravljanju zakonodajne funkcije te organizacije. Prispevek zaključuje $z$ mnenjem, da je $v$ institucionalni ureditvi EU prevladalo načelo racionalnosti nad načelom demokratičnosti.

Ključne besede: Evropska unija, izvršilna oblast, nacionalni parlamenti, zakonodajna funkcija, legitimnost institucij EU

\section{Primat izvršilne oblasti držav članic v institucijah EU}

Po ustanovitvenih pogodbah Evropskih skupnosti in po Pogodbi o Evropski uniji (PEU) nacionalni parlamenti nimajo možnosti, da bi neposredno sodelovali pri izvrševanju tistih suverenih pravic, ki so jih države članice prenesle v izvrševanje na te skupnosti oziroma na EU. V EU sodelujejo pri izvrševanju teh pravic predvsem tiste institucije, ki se formirajo iz vlad in šefov držav članic kot nosilcev izvršilne oblasti v teh državah. Evropski parlament ima na odločanje o izvrševanju teh pravic omejen vpliv. Nacionalni parlamenti neposredno lahko sodelujejo samo pri pripravi sprememb in dopolnitev ustanovitvenih in pristopnih pogodb ter pri njihovi ratifikaciji, izdajajo predpise za "dosego rezultata" tistih pravnih aktov, ki niso neposredno v veljavi v državah članicah (direktive, po novem evropski okvirni zakoni), in politično nadzorujejo vlade držav članic pri opravljanju zadev iz pristojnosti EU.

Politični primat vlad in šefov držav (Francija) v institucijah EU izhaja predvsem iz sestave in funkcije Evropskega sveta. Evropski svet je institucija EU v širšem pomenu, $\checkmark$ okviru katere se sestajajo predsedniki vlad in šefi držav ter predsednik Komisije EU, pri čemer jim pomagajo ministri za zunanje zadeve. Po svoji sestavi in funkciji je Evropski svet strateško središče Evropske unije. 

parlamentov držav članic v Evropski uniji

Med sedanjo pravno ureditvijo Evropskega sveta in predlaganimi spremembami $\checkmark$ osnutku ustavne pogodbe o EU ni večjih vsebinskih razlik. Po sedanji in predvideni pravni ureditvi, z nekaterimi redakcijskimi razlikami, daje Evropski svet ustrezen zagon za razvoj EU in določa splošne politične smernice za njeno delovanje. Tako je doslej odločilno vplival na širjenje EU in na oblikovanje njene institucionalne ureditve ter na dinamiko njene gospodarske in politične integracije. Z uvedbo stalnega predsednika Evropskega sveta, ki bo, kot predvideva osnutek ustavne pogodbe, izvoljen za dve leti in pol in bo predsedoval tudi sejam sveta, bo položaj Evropskega sveta še močnejši.

Vlade držav članic sporazumno imenujejo - po predhodni odobritvi kandidatur v Evropskem parlamentu - tudi predsednika in člane komisije (s petletnim mandatom), ki je dejansko predlagateljica vseh pravnih aktov iz pristojnosti Evropske unije. Kljub temu da vlade držav članic odločajo o oblikovanju Komisije EU, je njihov vpliv na njeno delovanje minimalen. Člani komisije so namreč pri opravljanju svojih nalog v "splošnem interesu popolnoma neodvisni in ne smejo pri opravljanju teh nalog zahtevati ali sprejemati nikakršnih navodil od posameznih vlad ali drugih organov" (2. točka 213. člena PES ).

Osnutek ustavne pogodbe predvideva povsem drugačno oblikovanje in sestavo komisije. Po tem osnutku naj bi bila komisija sestavljena iz predsednika, zunanjega ministra EU in trinajstih članov ter določenega števila pridruženih članov brez glasovalne pravice, ki jih imenuje predsednik komisije, s tem da bi bile z rotacijo članov $v$ komisiji enakopravno zastopane vse države članice (25. člen osnutka pogodbe). Predlagane spremembe so politični kompromis med majhnimi državami, ki so po načelu legitimnosti zagovarjale zastopanost vseh držav članic $v$ komisiji, in velikimi državami, ki so se po načelu avtonomnosti in funkcionalnosti zavzemale za omejitev števila njenih članov (prim. Brinar, 2001, str. 191).

Komisija ima izključno pravico do zakonodajne iniciative in dolžnost, da na podlagi te pravice vloži v zakonodajni postopek predloge vseh pravnih aktov, katerih sprejem je potreben za izpolnjevanje nalog iz pristojnosti Evropskih skupnosti. Svet lahko nastopi v funkciji predlagatelja samo tako, da naloži komisiji, naj "mu izdela raziskave, za katere svet meni, da so primerne za dosego skupnih ciljev, in mu predloži ustrezne predloge" (208. člen PES). Tudi Evropski parlament lahko zahteva, da mu komisija pripravi ustrezne zakonodajne predloge (192. člen PES). Toda v praksi je število takšnih zahtev sveta in Evropskega parlamenta zanemarljivo.

Normodajni primat nosilcev izvršilne oblasti držav članic $v$ institucijah EU izhaja predvsem iz sestave in funkcije sveta te organizacije. Svet je po svoji sestavi in po svojih pristojnostih izrazito ambivalentna institucija, ki ni razložljiva s tradicionalnimi političnimi in pravnimi teorijami, predvsem pa ne z načelom delitve oblasti. Svet je tista institucija, po kateri vlade držav članic (ministri), ki so v teh državah dejanske nosilke izvršilne oblasti, opravljajo v EU zakonodajno funkcijo. Po svoji funkciji je svet, kot ugotavlja tudi pravna teorija, de facto zakonodajalec EU (Grilc, Ilešič, 2001, str. 173). Svet EU izdaja na predlog Komisije EU, samostojno ali po postopku soodločanja skupaj z Evropskim svetom, uredbe in direktive. Nacionalni parlamenti nimajo pri sprejemanju teh aktov nikakršnega neposrednega vpliva. Kljub temu imajo ti pravni akti višjo pravno 


\section{Rudi Kocjančič}

Vloga nosilcev izvršilne oblasti in parlamentov držav članic v Evropski uniji

veljavo kot pravni akti nacionalnih parlamentov. Po precedenčnih odločitvah Sodišča skupnosti imajo ti pravni akti celo višjo veljavo kot nacionalne ustave. Osnutek ustavne pogodbe pa izrecno določa, da ima pravo EU primat nad pravom držav članic (1. točka 9. člena). Na podlagi skupnih strategij o zunanji in varnostni politiki, ki jih oblikuje Evropski svet po priporočilu Sveta EU, lahko sprejema Svet EU tudi skupne ukrepe in skupna stališča za izvrševanje teh strategij (14. in 15. člen PEU).

Po spremembah načina glasovanja, ki jih predvideva osnutek ustavne pogodbe, naj bi bil Svet EU še samostojnejši in po pričakovanju pripravljalcev osnutka še učinkovitejši. Ustavna pogodba naj bi ga okrepila predvsem z omejitvijo njegovega odločanja s soglasjem in razširitvijo njegovega odločanja s kvalificirano večino. Po ustavni pogodbi bi morala kvalificirana večina predstavljati večino držav članic, katerih prebivalstvo obsega vsaj tri petine vsega prebivalstva EU (1. točka 24. člena).

Pri izvrševanju zakonodajne funkcije sveta sodelujejo stalna in občasna delovna telesa ter pristojni odbori. Med njimi je najvplivnejši in najpomembnejši Odbor stalnih predstavnikov (Coreper), dejansko delujoč kot Coreper II, ki ga sestavljajo veleposlaniki kot stalni predstavniki držav članic, in kot Coreper I, ki ga sestavljajo njihovi namestniki. $V$ delo tega organa so vključene številne delovne skupine, ki jih sestavljajo uradniki držav članic in uradniki strokovnih služb sveta in komisije. Politična javnost označuje skupek subjektov, ki neposredno sodelujejo pri strokovni in politični pripravi aktov in odločitev sveta in komisije, "komitologija". Poznavalci ilustrirajo njeno moč s trditvijo, po kateri naj bi svet "nekatere dokumente sprejel celo brez politične razprave", s trditvijo, da "odbori $\vee 70 \%$ primerov zakonodajnih aktov $\vee$ pogajanjih sveta dejansko nastopajo kot zadnji arbitri", in s trditvijo, po kateri naj bi "po grobi oceni 80 \% aktov sprejela strokovna uprava" (po Weiler, 2001, str. 339). Te trditve so $\checkmark$ bistvu primerljive z empiričnimi ugotovitvami, po katerih sprejmejo sodobni parlamenti okrog 80-90 \% zakonov na predlog vlade (Zajc, 2000, str. 69).

Edina institucija, ki ne izhaja iz nosilcev izvršilne oblasti držav članic, je Evropski parlament, ki ga neposredno izvolijo državljani. V primerjavi z nacionalnimi parlamenti, ki so kot predstavniška telesa ljudstva po načelu delitve oblasti nosilci zakonodajne oblasti, lahko Evropski parlament v okviru svoje zakonodajne funkcije samo soodloča skupaj s Svetom EU o sprejemu pravnih aktov na določenih področjih (posvetovanja, sodelovanja, soodločanja, privolitve). Osnutek ustavne pogodbe predvideva opustitev postopka soodločanja in določa samo, da "Evropski parlament skupaj s svetom sprejema zakonodajo" (1. točka 19. člena). Z okrepitvijo zakonodajne funkcije Evropskega parlamenta bo porasla tudi politična moč parlamentarnih skupin v njem, vse večji pa bo tudi vpliv njegovih delovnih skupin in strokovnih služb na njegovo delo. Evropski parlament ima tudi nadzorno funkcijo (poslanska vprašanja, glasovanje o nezaupnici komisiji) in proračunsko funkcijo (predvsem pri odločanju o neobvezni porabi).

Del politične javnosti $\vee$ Evropi se zavzema za federalizacijo EU in za uvedbo dvodomnega evropskega parlamenta kot predstavnika državljanov in kot predstavnika narodov oziroma držav. Tudi po prvem besedilu osnutka ustavne pogodbe naj bi EU izvrševala nekatere skupne pristojnosti na "federalni osnovi". V poznejšem besedilu osnutka so njegovi pripravljalci opustili pojem "federativna osnova". Člani Evropske 
konvencije iz Slovenije so s posebnim amandmajem zavrnili idejo o "federativni osnovi" z obrazložitvijo o "slabih izkušnjah Slovenije v nekdanji zvezni državi". Toda sama "federativna osnova" ni teoretično niti politično sporna za odločanje o nekaterih skupnih pristojnostih v EU (Kristan, 2003, str. 9). Slovenska javnost pa zavrača pobude za preoblikovanje EU $\vee$ nekakšno nadnacionalno evropsko federacijo, ki bi temeljila na enotnem evropskem ljudstvu ali celo na enotnem evropskem narodu (Glej Ribičič, 2003, str. 106).

Kaže pa, da je med političnimi, gospodarskimi in uradniškimi elitami v Evropi prevladalo mnenje, da politični primat nosilcev izvršilne oblasti držav članic $\vee$ institucijah EU zagotavlja racionalnejše in učinkovitejše opravljanje nalog iz pristojnosti te organizacije kot morebitni klasični primat strankarsko razcepljenega in politično paraliziranega Evropskega parlamenta.

Sodišče Evropskih skupnosti je za pričujoči prikaz vloge nosilcev izvršilne oblasti držav članic v institucijah EU pomembno predvsem kot nekakšen "sekundarni zakonodajalec", ki je izoblikoval temeljna načela, s katerimi je opredelil razmerje med pravom EU in pravom držav članic te organizacije (avtonomnost in primarnost prava EU ter njegova neposredna uporabnost $v$ državah članicah te organizacije).

Države članice EU so torej v okviru svojih suverenih pravic, ki jih same neposredno izvršujejo, obdržale predstavniško demokracijo, v institucijah EU pa je bila vzpostavljena nekakšna "delegirana demokracija" z vprašljivo stopnjo legitimnosti (O'Donell, 1994, str. 17).

\section{Marginalizacija nacionalnih parlamentov v EU}

Politične elite, ki so snovale in oblikovale institucionalno ureditev EU, so že zgodaj ugotovile, da bi lahko izločitev nacionalnih parlamentov iz neposrednega procesa oblikovanja in sprejemanja pravnih aktov ter politik te organizacije ogrozila legitimnost njenih institucij in izzvala odpor državljanov in javnosti zoper to organizacijo. Očitno je bila na podlagi te ugotovitve že k Maastrichtski pogodbi iz leta 1992 sprejeta Deklaracija o vlogi nacionalnih parlamentov $\vee$ Evropski uniji (št. 13), ki je poudarjala potrebo po izmenjavi informacij med nacionalnimi parlamenti in Evropskim parlamentom ter potrebo, da bi vlade držav članic pravočasno dostavile zakonodajne predloge komisije parlamentom teh držav. Namesto te deklaracije je bil k Amsterdamski pogodbi iz leta 1997 sprejet Protokol o vlogi nacionalnih parlamentov v Evropski uniji (št. 9). Protokol določa, da morajo biti zakonodajni akti komisije "pravočasno na voljo, da lahko vlada vsake države članice zagotovi, če je to primerno, njihovo predložitev nacionalnemu parlamentu" (2. točka I. razdelka). Tudi po tem protokolu parlamenti držav članic lahko sodelujejo v zakonodajnem postopku EU samo po vladah teh držav. Protokol je vladam celo priznal pravico, da po lastni arbitrarni presoji odločajo ("če je to potrebno"), kdaj naj sploh predložijo zakonodajne predloge nacionalnim parlamentom. $\vee$ tem pomenu je sodelovanje nacionalnih parlamentov pri obravnavi zakonodajnih predlogov Evropske unije implicite odvisno od politične volje vlad. Protokol je s to določbo ogrozil tudi politično nadzor nacionalnih parlamentov nad delom svojih vlad $\vee$ zakonodajnem 


\section{Rudi Kocjančič}

Vloga nosilcev izvršilne oblasti in parlamentov držav članic v Evropski uniji

postopku te organizacije. Nacionalni parlamenti namreč ne morejo nadzorovati svojih vlad $\vee$ zakonodajnem postopku EU, ne da bi poznali zakonodajne predloge te organizacije in ne da bi imeli možnost, da se do njih opredelijo (prim. Lenaerts, Nuffel, 1999, str. 388-392).

Protokol o vlogi nacionalnih parlamentov $\vee$ EU $v$ posebnem razdelku ureja tudi položaj in vlogo Konference odborov za evropske zadeve (Cosac). Po protokolu se konferenca lahko opredeli tudi do osnutkov pravnih besedil in preuči vsak zakonodajni predlog, ki bi lahko neposredno vplival na pravice in svoboščine posameznikov. Njene opredelitve pa ne zavezujejo nacionalnih parlamentov in ne prejudificirajo njihovih stališč.

Protokol o uporabi načel o subsidiarnosti in sorazmernosti, ki je bil sprejet $k$ Amsterdamski pogodbi, pa ne omenja nacionalnih parlamentov.

Deklaracija o prihodnosti Evropske unije iz Nice je samo načelno odprla vprašanja o vlogi nacionalnih parlamentov v "evropski arhitekturi". Šele deklaracija iz Laekna je sistemsko problematizirala pravno ureditev in delovanje institucij EU. Deklaracija je namreč odprla dve ključni vprašanji, in sicer vprašanje o morebitni neposredni institucionalni vključitvi - poleg Sveta EU in Evropskega parlamenta - nacionalnih parlamentov $v$ to organizacijo in vprašanje o morebitnem sodelovanju nacionalnih parlamentov pri urejanju tistih področij, na katerih Evropski parlament nima pristojnosti. Vprašanji sta bili odprti $\vee$ trenutku politične diagnoze o demokratičnem primanjkljaju $\vee$ institucijah EU (zaprtost in nepreglednost dela Sveta EU, omejena vloga Evropskega parlamenta, nezadovoljiv vpliv nacionalnih parlamentov na te institucije). $V$ pripravah na Konvencijo o prihodnosti Evropske unije pa so politične elite te radikalne glasove prepustile pozabi.

Tudi Evropska konvencija ni opustila politične filozofije, ki je pravno formalizirana $\checkmark$ ustanovitvenih pogodbah Evropskih skupnosti ter $v$ PEU in ki zavrača neposredno sodelovanje nacionalnih parlamentov $v$ institucijah EU. Osnutek ustavne pogodbe o EU sistemsko ni posegel $\vee$ dosedanjo pravno ureditev vloge nacionalnih parlamentov pri nadzoru načel subsidiarnosti in sorazmernosti ter njihove vloge $\vee$ zakonodajnem postopku te organizacije. $V$ preambuli samo deklarativno poudarja potrebo po krepitvi vpliva nacionalnih parlamentov pri zagotavljanju legitimnosti "evropskega projekta". V normativnem delu osnutek določa, da nacionalni parlamenti sodelujejo pri zagotavljanju spoštovanja načela subsidiarnosti po postopku, ki ga ureja Protokol o uporabi načel subsidiarnosti in sorazmernosti (9. člen). V poglavju o demokratičnem življenju v EU pa določa, da so seje Evropskega sveta in Sveta EU pri obravnavi zakonodajnih predlogov javne. Evropska konvencija je kot prilogi k ustavni pogodbi sprejela tudi osnutek novega protokola o uporabi načel subsidiarnosti in sorazmernosti ter osnutek novega protokola o vlogi nacionalnih parlamentov $\vee$ EU, ki urejata postopek sodelovanja nacionalnih parlamentov pri sprejemanju pravnih aktov te organizacije.

Za krepitev vloge nacionalnih parlamentov $v$ EU je najpomembnejša novost obeh osnutkov, da določata (z nekaterimi redakcijskimi razlikami), da komisija predloži svoje zakonodajne predloge nacionalnim parlamentom, in to hkrati kot Evropskemu parlamentu in Svetu EU. Po novih protokolih bi torej komisija pošiljala zakonodajne predloge 

parlamentov držav članic v Evropski uniji

nacionalnim parlamentom neposredno in ne več - kot po veljavni pravni ureditvi - po vladah držav članic. Pomembna novost je tudi, da bi komisija pošiljala zakonodajne predloge nacionalnim parlamentom hkrati kot Evropskemu parlamentu in Svetu EU. Po novi ureditvi bi tako imeli nacionalni parlamenti neposreden, sproten in celovit pregled nad zakonodajnimi predlogi komisije. Osnutek protokola o vlogi nacionalnih parlamentov $\vee$ EU $\vee$ posplošeni določbi (9. točka) tudi določa, da lahko Konferenca odborov za evropske zadeve (Cosac) pripravi kakršen koli prispevek, s katerim bi bilo po njenem mnenju primerno seznaniti Evropski parlament, Svet EU in Komisijo EU.

Po osnutku protokola o uporabi načela subsidiarnosti in sorazmernosti bi imeli nacionalni parlamenti tudi pravico pošiljati predsednikom Evropskega parlamenta, Sveta EU in Komisije EU obrazloženo mnenje o morebitnem - po svoji presoji - neskladju zakonodajnih predlogov z načelom subsidiarnosti, s tem da bi Evropski parlament, Svet EU in Komisija EU upoštevali njihova mnenja pri odločanju $v$ zakonodajnem postopku (5. točka). Po osnutku protokola o vlogi nacionalnih parlamentov $\vee$ EU pa bi morala komisija poslati nacionalnim parlamentom $\vee$ vednost tudi vse instrumente zakonodajnega planiranja in strategijo politik, ki jih posreduje Evropskemu parlamentu in Svetu EU, in to hkrati kot tema institucijama (6. točka).

Kot določa tudi Protokol o vlogi nacionalnih parlamentov v Evropski uniji, je nadzor nacionalnih parlamentov nad njihovimi vladami $\vee$ zadevah, ki so $\vee$ pristojnosti te organizacije, "predmet posebnega ustavnega ustroja in prakse držav članic". V državah članicah te organizacije poznajo različne pravne ureditve in prakse sodelovanja med vladami in parlamenti teh držav. Tako v nekaterih državah vlade samo obveščajo parlamente o svojem delu in o delu svojih ministrov $v$ zakonodajnem postopku, $v$ drugih državah pa parlamenti praviloma $\vee$ delovnih telesih obravnavajo zakonodajne predloge in sprejemajo o njih stališča, ki politično zavezujejo vlade pri opredeljevanju do teh predlogov. Ministri oziroma vlade skandinavskih držav potrebujejo pri odločanju o pomembnejših zakonodajnih predlogih $\vee$ EU celo soglasje svojih parlamentov (Vehar, št. 40/2002, II-IV).

Po sprejemu novih protokolov, po katerih naj bi torej komisija neposredno pošiljala svoje zakonodajne predloge nacionalnim parlamentom, bo treba tudi pravno prenoviti postopke za obravnavo teh predlogov $v$ nacionalnih parlamentih. Nacionalni parlamenti bi se morali opredeljevati predvsem do tistih zakonodajnih predlogov, katerih vsebino bi po notranjem pravu sami urejali. Eno od vprašanj je tudi, ali naj vse zakonodajne predloge obravnavajo izključno parlamentarna delovna telesa, ali pa naj pomembnejše predloge obravnavajo tudi parlamenti na plenarnih zasedanjih. Posebno vprašanje je stopnja politične vezanosti vlad na stališča njihovih parlamentov. Preveč toga stališča parlamentov bi lahko omejila pogajalske možnosti vlad in otežila sklepanje širših političnih kompromisov.

Toda zadeve, ki so v pristojnosti EU, so čedalje kompleksnejše in protislovnejše, zato je tudi odločanje o zakonodajnih predlogih komisije čedalje zahtevnejše. Tudi po sprejemu novih protokolov, ki naj bi formalno omogočili večji vpliv nacionalnih parlamentov na zakonodajni postopek EU, njihov dejanski vpliv na ta postopek ne bo bistveno večji. Po načelu, ki ga Luhmann označuje kot "Legitimation durch Verfahren" 


\section{Rudi Kocjančič}

Vloga nosilcev izvršilne oblasti in parlamentov držav članic v Evropski uniji

(Luhmann, 1969, str. 95), bodo o zakonodajnih predlogih $\vee$ okviru pristojnosti sveta dejansko odločale vlade držav članic v sodelovanju s "komitologijo", nacionalni parlamenti pa bodo dajali njihovim odločitvam kvečjemu večjo ali manjšo formalno legitimnost. Vloga nacionalnih parlamentov $v$ EU bo tudi vnaprej normativno in dejansko marginalna.

\section{Razmere med državnim zborom in vlado v okviru pristojnosti EU}

Slovenija spada med tiste države pristopnice, ki bodo na podlagi ustavnih sprememb z zakonom uredile razmerje med parlamentom in vlado $v$ okviru pristojnosti EU. Ustavna podlaga za sprejem tega zakona je Ustavni zakon o spremembah I. poglavja ter 47. in 68. člena Ustave RS.

Neposredna podlaga za sprejem tega zakona je 4. odstavek 3.a člena, ki določa: " $V$ postopkih sprejemanja pravnih aktov in odločitev $\vee$ mednarodnih organizacijah, na katere Slovenija prenese izvrševanje dela suverenih pravic, vlada sproti obvešča državni zbor o predlogih takih aktov in odločitev ter o svoji dejavnosti. Državni zbor lahko o tem sprejema stališča, vlada pa jih upošteva pri svojem delovanju. Razmerja med državnim zborom in vlado iz tega odstavka podrobneje ureja zakon, ki se sprejme z dvotretjinsko večino navzočih poslancev". Po vsebini je ta določba primerljiva z ustavno ureditvijo razmerja med parlamentom in vlado glede zadev EU $\vee$ večini drugih držav.

Po prvem stavku $\vee$ zgornji ustavni določbi je torej vlada dolžna, da $\vee$ postopkih sprejemanja pravnih aktov in odločitev $\vee$ EU obvešča državni zbor o predlogih teh aktov in odločitev. Besedilo te določbe bi bilo še ustreznejše, če bi zavezovalo vlado, da predloge teh aktov predloži državnemu zboru, in sicer čim jih prejme. Zakonodajni predlogi so preveč pomembni, da bi vlada o njih samo obveščala državni zbor.

Po drugem stavku v zgornji določbi državni zbor lahko sprejema stališča o predlogih pravnih aktov in odločitev EU. Tudi državni zbor lahko vpliva na opredeljevanje in glasovanje vlade $\vee$ zakonodajnem postopku te organizacije samo s svojimi stališči. Vlada je dolžna, da ta stališča upošteva pri svoji dejavnosti. Toda ta stališča ne vplivajo na veljavnost opredeljevanja in glasovanja vlade $v$ institucijah EU.

Vlada je samostojna tudi pri opravljanju zakonodajne funkcije $\vee$ tej organizaciji, hkrati pa je za opravljanje te funkcije odgovorna državnemu zboru. Državni zbor lahko s svojimi stališči samo politično zavezuje vlado. Tudi glede na kompleksnost in zahtevnost nalog iz pristojnosti EU ter glede na potrebo po pogajalskih pooblastilih vlade bi bila preveč ozka stališča državnega zbora neuporabna. Zato bo tudi zakon, ki bo uredil razmerje med državnim zborom in vlado $v$ okviru pristojnosti EU, težko določneje opredelil stopnjo vezanosti vlade na stališča državnega zbora. Po razširitvi EU $\checkmark$ letu 2004 in po uveljavitvi njene ustavne pogodbe, ki bo omejila odločanje sveta s soglasjem in razširila njegovo odločanje s kvalificirano večino, bodo nacionalni parlamenti še težje vplivali na opravljanje zakonodajne funkcije $v$ tej organizaciji.

Po ustavnem zakonu bo torej državni zbor sprejemal stališča o predlogih pravnih aktov in odločitev $v$ EU. Toda glede na potrebo po racionalizaciji in specializaciji svojega 
dela ter glede na kompleksnost in zahtevnost nalog iz pristojnosti EU bo državni zbor težko neposredno sprejemal stališča o predlogih teh aktov. Praviloma bo stališča o teh predlogih sprejemal $\vee$ enem ali več delovnih telesih. Zakon bo predvidel, ali bo stališča sprejemalo pristojno matično telo po vsebini, posebno delovno telo za evropske zadeve ali delovno telo za določeno področje, denimo za zunanje zadeve. Po načelu racionalnosti bo seveda državni zbor na plenarnih sejah sprejemal stališča samo o najpomembnejših zakonodajnih in političnih predlogih. Doslej je državni zbor na plenarnih sejah obravnaval, dopolnjeval in potrjeval pogajalska izhodišča vlade v postopku prevzemanja pravnega reda Evropskih skupnosti.

Pravna ureditev razmerja med državnih zborom in vlado $v$ ustavnem zakonu je primerljiva predvsem s pravnimi ureditvami razmerja med parlamenti in vladami v skandinavskih državah. Med temi državami izstopa Danska, $v$ kateri je parlament intenzivno in kontinuirano nadzoroval izvršilno oblast $\vee$ vseh fazah vključevanja $\vee$ EU. V tej državi obravnava zadeve iz pristojnosti EU in se do njih opredeljuje odbor za evropske zadeve. Odbor tudi preuči vse vladne predloge o teh zadevah in o njih sprejme stališča. Do zadev, ki jih obravnava odbor, se opredelijo tudi matična delovna telesa. Na Finskem sprejema politično zavezujoča mnenja za delo vlade veliki odbor po predhodni pridobitvi mnenj matičnih delovnih teles. Na Švedskem se vlada posvetuje o svojem delu in o svoji politiki $v$ institucijah EU s svetovalnim odborom kot posebnim parlamentarnim delovnim telesom. Mnenja tega telesa niso obvezujoča za vlado, vendar jih vlada običajno upošteva (Vehar, št. 40/2002, III-V).

Po vstopu Slovenije $\vee$ EU bo torej razmerje med državnim zborom in vlado ambivalentno: po ustavni ureditvi Slovenije bo razmerje med državnim zborom in vlado urejeno po načelu delitve oblasti, po katerem je državni zbor nosilec zakonodajne, vlada pa dejanski nosilec izvršilne oblasti, po evropskem pravu pa bo vlada po Svetu EU sodelovala pri opravljanju zakonodajne funkcije te organizacije, državni zbor pa bo lahko $\checkmark$ zakonodajnem postopku te organizacije sprejemal samo stališča o zakonodajnih predlogih $\vee$ tem postopku.

$\checkmark$ tretjem stavku zgoraj navedene določbe ustavni zakon tudi določa, da se zakon, ki ureja razmerja med državnim zborom in vlado, sprejme z dvotretjinsko večino glasov navzočih poslancev. Ustavna komisija je utemeljila predpisano večino za sprejem tega zakona z obrazložitvijo, da sodi ureditev delitve oblasti med vlado in državnim zborom $\checkmark$ okviru izvrševanja dela suverenih pravic Slovenije $\vee$ EU - v ustavno materijo. Ustavna komisija utemeljuje predpisano večino za sprejem tega zakona tudi z mnenjem, po katerem je $\vee$ parlamentarnem sistemu delitev oblasti med parlamentom in vlado že po naravi stvari precej "izvotljena", ker vlada izvira iz parlamentarne večine in so tako njena stališča in interesi $v$ veliki meri enaki stališčem in interesom parlamentarne večine. S tem mnenjem je odprla tudi aktualno in pomembno vprašanje, koliko državni zbor tudi dejansko lahko vpliva na oblikovanje in sprejemanje pravnih aktov in odločitev EU.

$\checkmark$ sodobnih parlamentarnih sistemih, $v$ katerih sta parlament in vlada odvisna od razmerja moči političnih strank $\vee$ parlamentu, je namreč preseženo tudi načelo delitve oblasti $\vee$ klasičnem pomenu (Šturm, 1998, str. 16-17). Glede na to, da za 


\section{Rudi Kocjančič}

Vloga nosilcev izvršilne oblasti in parlamentov držav članic v Evropski uniji

odločanje v parlamentu praviloma zadostuje večina vseh poslancev, politična stranka ali koalicija, ki ima v parlamentu večino, obvladuje parlament, po parlamentu pa tudi vlado. Politična premoč strankarskih oligarhij nad parlamentom in vlado lahko privede celo do dejanske enotnosti oblasti (prim. Grad, 1996, str. 113).

Tudi državni zbor obvladuje strankarska koalicija, ki ima $v$ njem večino, po državnem zboru pa koalicija obvladuje tudi vlado. Državo dejansko upravlja vlada s politično podporo vladne koalicije $v$ državnem zboru. Tako je od začetka leta 1993, ko sta državni zbor in vlada dejansko začela delo, do srede leta 2003 državni zbor sprejel 89 \% zakonov na predlog vlade, vlada pa je sicer tudi izključna predlagateljica državnega proračuna. Po vstopu Slovenije $\vee$ EU bodo strankarske oligarhije, ki po svoji politični volji oblikujejo vlado in ki jim je vlada tudi dejansko odgovorna, odločale tudi o politični naravi stališč državnega zbora o zakonodajnih predlogih EU in o odgovornosti vlade za opravljanje njene zakonodajne funkcije $\vee$ tej organizaciji.

$\checkmark$ procesu racionalizacije in profesionalizacije politike, ki ga je prvi v klasični obliki identificiral in formuliral M. Weber (M. Weber, 1992, str. 30-40), se tudi ciklus vladnih aktivnosti pri opravljanju zakonodajne funkcije $v$ EU začenja in - $v$ fazi izvrševanja - tudi končuje pri državni upravi. Ključno vprašanje Slovenije ob vstopu v EU je, kako zagotoviti politično kompetentnost vlade in strokovno kompetentnost državne uprave pri sodelovanju $v$ institucijah te organizacije.

\section{Zaključek}

Kljub deklarativnim ugotovitvam o nezadovoljivi legitimnosti institucij EU in kljub ugotovitvam o demokratičnem primanjkljaju pri njihovem delu osnutek ustavne pogodbe ne predvideva sistemskih sprememb te organizacije. Politična retorika o večji vlogi nacionalnih parlamentov $v$ "evropski arhitekturi" se končuje z osnutkom protokola o uporabi načel subsidiarnosti in sorazmernosti ter z osnutkom protokola o vlogi nacionalnih parlamentov $\vee$ EU, ki ne odpirata novih institucionalnih možnosti za sodelovanje nacionalnih parlamentov pri opravljanju zakonodajne funkcije te organizacije. $V$ poglavju o demokratičnem življenju $\vee$ EU pa osnutek ustavne pogodbe zgolj posplošeno označuje načela in možnosti za sodelovanje državljanov in njihovih združenj $\checkmark$ javnem življenju te organizacije. Tudi po predvideni ustavni ureditvi EU bodo nacionalni parlamenti zgolj nekakšna delovna telesa $\vee$ zakonodajnem postopku te organizacije s pravico do sprejemanja stališč o zakonodajnih predlogih $v$ tem postopku.

Po drugi strani je sistemski primat nosilcev izvršilne oblasti držav članic EU primerljiv z dejansko močjo izvršilne oblasti v teh državah. Vlade, ki imajo podporo ene stranke ali strankarske koalicije z večino $v$ parlamentu, tudi dejansko odločajo o upravljanju države. Ustanovitvene pogodbe Evropskih skupnosti in PEU so pravno formalizirale politično moč nosilcev izvršilne oblasti držav članic EU po načelu racionalnosti.

$\checkmark$ institucionalni ureditvi EU je prevladalo načelo racionalnosti nad načelom demokratičnosti. Vprašanje legitimnosti institucij te organizacije in vprašanje demokratičnega primanjkljaja pri njihovem delu sta sistemski vprašanji, ki bosta aktualni tudi po sprejemu in uveljavitvi ustavne pogodbe. Za Slovenijo je pred vstopom 

parlamentov držav članic v Evropski uniji

v EU pomembnejše vprašanje, kako čim bolj politično in strokovno kompetentno sodelovati $\vee$ njenih institucijah. Med strateške subjekte za delo v njenih institucijah sodi tudi slovenska uradniška elita.

\section{Literatura}

- Brinar, I., Strukturni vidiki pogodbe iz Nice, v: VII. Dnevi javnega prava, zbornik, Portorož 2001.

- Grad, F., idr., Državna ureditev Slovenije, ČZ UL RS, Ljubljana 1996.

- Grilc, P., Ilešič, T., Pravo Evropske unije, prva knjiga, Pravna obzorja, Ljubljana 2001.

- Kristan, I., Evropska ustava in federalizem, samostojen referat, IX. Dnevi javnega prava, Portorož 2003.

- Lenaerts, K., Nuffel, P., Constitutional Law of the European Union, London 1999.

- Luhmann, N., Legitimation durch Verfahren, Neuwied and Berlin: Luchter-hand, 1969.

- O'Donell, G., Delegative democracy, Journal of Democracy, 1994/1.

- Ribičič, C., Mozaik ustavnih sprememb, GV Založba in Pravna praksa, Ljubljana 2003.

- Šturm, L., Omejitev oblasti, Nova revija, Ljubljana 1998.

- Weber, M., Politika kot poklic, zbornik, Krt, Ljubljana 1992.

- Vehar, P., Nacionalni parlamenti in njihova vloga v Evropski uniji, Pravna praksa, priloga, št. $45 / 2002$.

- Weiler, J. H. H., Ustava Evrope, Pravna fakulteta v Ljubljani, Ljubljana 2002.

- Zajc, D., Parlamentarno odločanje, Fakulteta za družbene vede, Ljubljana 2000.

\section{Viri}

- Ustavni zakon o spremembah I. poglavja ter 47. in 68. člena Ustave Republike Slovenije, Uradni list RS, št. 24/2003.

- Temeljni akti Evropskih skupnosti, Uradni list RS, Ljubljana 2002.

- Entwurf eines Vertrags über eine Verfassung für Europa, Brüssel, 27. junij 2003.

Dr. Rudi Kocjančič je dolgoletni nosilec predmeta Ustavno pravo na Fakulteti za upravo. Objavil je več znanstvenih in strokovnih del s področja pravne ureditve človekovih pravic in temeljnih svoboščin, državne ureditve in teorije prava. V letu 1991 je bil član Delovne skupine za lokalno samoupravo in član Delovne skupine za ustavnost in zakonitost pri ustavni komisiji za pripravo Ustave Republike Slovenije. Sodeloval je na različnih strokovnih srečanjih. Je urednik znanstvenih publikacij in član uredništev strokovnih revij. 
Rudi Kocjančič

Vloga nosilcev izvršilne oblasti in

parlamentov držav članic v Evropski uniji

\section{SUMMARY}

\section{The Role of the Holders of Executive Authority and the Parliaments of the European Union Member States}

According to the Treaties establishing the European Communities and to the European Union Treaty, national parliaments do not have the possibility of direct participation in exercising those sovereign rights, which the Member States transferred for implementation to these Communities or the European Union. Within the European Union, the institutions participating in exercising these rights are especially those, which are formed out of governments and heads of Member States, who represent the holders of executive authority in these states. Even the European Parliament has a limited influence on the exercising of these rights. In the legislative procedure of this organisation, national parliaments only have the right to adopt positions on legislative proposals in this procedure. The political primacy of the holders of executive authority in this organisation especially arises from the composition and function of the European Council, while the regulatory one arises especially from the composition and function of the Council.

Despite the declarative findings about the unsatisfactory legitimacy of the European Union institutions and the findings about the democratic deficiency in their work, the Draft Constitutional Treaty does not provide any system changes of this organisation. Neither do the draft Protocol on the application of the principles of subsidiarity and proportionality and the draft Protocol on the role of national parliaments in the European Union open up the possibility of direct participation of national parliaments in the performance of the legislative function of this organisation. Also according to the foreseen constitutional system of the European Union, the national parliaments will only have the right to adopt positions on legislative proposals in the legislative procedure of this organisation.

In the institutional system of the European Union, the principle of rationality prevailed over the principle of democracy. The Treaties establishing the European Communities and the European Union Treaty have legally formalized the political power of the holders of executive authority of the European Union Member States according to the principle of rationality. The question of legitimacy of the institutions of this organisation and the question of democratic deficiency in their work are system questions which will also be relevant after the adoption and the enforcement of the Constitutional Treaty. 